Ana Njegovan, mag.oec.

Fakultet za menadžment u turizmu i ugostiteljstvu, Sveučilište u Rijeci, Rijeka, Republika Hrvatska

ananjegovan@gmail.com

doc. dr. sc. Lidija Bagarić

Fakultet za menadžment u turizmu i ugostiteljstvu, Sveučilište u Rijeci, Rijeka, Republika Hrvatska lidijab@fthm.hr

\title{
POTENCIJAL MRAČNOG TURIZMA KAO TURISTIČKOG PROIZVODA DESTINACIJE
}

Primljen: 23. siječnja 2019.

Prihvaćen: 26. kolovoz 2019.

https://doi.org/10.46458/27121097.2020.26.9

\section{Prethodno priopćenje}

\section{Sažetak}

Rastuća dimenzija suvremene turističke ponude u turističkom paketu postaju lokacije smrti, nesreće, tragedije i razna zlodjela jer pružaju potencijalno sadržajnija putovanja sa stajališta putnika. Sve više raste broj turista koji su u potrazi za diferenciranim, individualno krojenim $i$ duhovno vrijednim turističkim proizvodima, a među njima se nalaze i proizvodi koji zadiru u pitanje života i smrti ili „oživljavaju“ kontroverzne dijelove prošlosti. Kao rezultat potražnje za takvim proizvodima, poprilično emotivna etiketa prišila se na ovu vrstu turizma pod nazivom „mračni turizam", a koja je zaokupila javnost i akademsku zajednicu u kontinuiranom rastu potrebe za daljnjim istraživanjima. Međutim, usprkos pojačanom interesu, literatura je oskudna, a teorije prepune neodgovorenih pitanja i sumnji.

U ovom radu nastoji se, barem konceptualno, odrediti temeljne značajke mračnih proizvoda te karakteristike i percepciju mračne ponude kroz teoriju ,nijansi "lokacija i emocionalne težine koju potencijalna lokacija sadrži. Nadalje, ovo istraživanje rezultiralo je saznanjem kako mračni turistički proizvodi, različitih karakteristika i nijansi, mogu igrati veliku ulogu u unaprjeđenju turističke ponude destinacije. 
U radu su analizirani stavovi o samom pojmu mračnog turizma i približilo se odgovoru na pitanje je li mračni turizam prihvatljiv turistički proizvod te koliki je njegov značaj za turističku destinaciju.

Ključne riječi: selektivni turizam, mračni turizam, nijanse mračnog, destinacijski proizvod;

JEL: M31, O21, L83, R11

\section{UVOD}

Istraživanje $u$ ovom radu potaknuto je mnogobrojnim konfliktnim teorijama akademske zajednice o svrstavanju mračnog turizma u selektivne oblike turizma. Predmet istraživanja je uloga mračnog turizma u turističkom razvoju i kreiranju proizvoda destinacije. Osim teorijske podloge, provedeno je empirijsko istraživanje s ciljem boljeg uvida u ovu problematiku. Svrha istraživanja bila je prikupiti mišljenja i dojmove turista o pojmu ,mračni turizam“ i identificirati potencijalne proizvode takve vrste turizma te njihov potencijal plasmana na tržište. Istraživačko pitanje je može li mračni turizam privući konvencionalne turiste u manje ili više turistički razvijene lokacije, nudeći specifični mračni proizvod? Činjenica je da se turističke aktivnosti odvijaju i na lokalitetima na kojima turistička aktivnost nije predviđena pa su destinacije primorane osigurati turističku infrastrukturu, često u kratkom vremenskom roku. Rad se temelji na polazištu da se pravovremenim prepoznavanjem mračnog proizvoda, njegovom pažljivom i savjesnom razvoju i promociji, on može transformirati iz kontroverzne pojave do društveno prihvatljive kulturne znamenitosti i da u Hrvatskoj kao turističkoj destinaciji također postoji potražnja za mračnim proizvodima.

\section{TEORIJSKA PODLOGA}

Poznato je da u turizmu, u pravilu, potražnja pokreće ponudu. Za pojavu nove selektivne vrste turizma, potrebna je pojava dodatne potražnje, koju treba razlikovati od već postojeće, što znači da je po obliku i motivu nova. Takva nova ili uvjetno nova potražnja još je uvijek nepoznata ili uvjetno nepoznata tržištu potražnje te inicira razvoj dodatne ponude, koja oblikuje nove turističke proizvode. Tu je bitno da se radi o sub-turističkom fenomenu ili vrsti s novim pojavnim karakteristikama. (Luković 2008., 8). Ryan i Kohli (2006.) tvrde da vremenski, politički i ideološki čimbenici imaju velik utjecaj na percepciju posjetitelja u mračnih atrakcija, što djelomično može objasniti činjenicu da ponuda ipak ne drži korak s 
potražnjom. Prema Geiću, selektivni turizam predstavlja odgovor na probleme u suvremenom turizmu uzrokovane masovnim „hard“ turizmom i njegovom infrastrukturom te razvojem alternativnih oblika tzv. ,,soft“" turizma - putovanja koja nisu masovna, shematska i bezlična. (Geić, 2011., 303).

\subsection{Mračni turizam kao dio povijesno-kulturnog turizma}

Povijesno-kulturni turizam, iako malo usmjereniji od kulturnog, i dalje je širok pojam i dio je selektivnog turizma. Geić (2011., 303) tvrdi da su osnovne dvije motivacije novost i edukacija, što se može aplicirati na segment kulturnog turizma. Kulturni turizam je široko područje konstantno u razvoju i nadopunjavanju i koji stavlja naglasak na vrlo raširene interese pojedinca. Jedna od često korištenih definicija je i definicija G. Richardsa $(1996 ., 17)$ gdje je „kulturni turizam obilježen kretanjem ljudi uzrokovanim kulturnim atrakcijama izvan njihovog uobičajenog mjesta stanovanja s namjerom sakupljanja novih informacija $\mathrm{i}$ iskustava kako bi zadovoljili svoje kulturne potrebe." Slijedom navedenog može se reći da je mračni turizam putovanje turista kojim se među glavnim motivima nalazi istraživanje povijesnih događaja koji su rezultirali nepovoljnim ishodima, nesretnim slučajevima, smrću ili tragedijama.

Mračna destinacija je područje koje sadrži elemente mračnog turizma, a koji mogu privući skupinu turista u potrazi za takvim atrakcijama, no jednako tako i motivirati konvencionalnog turista posjećivanju mračnih elemenata $u$ istraživanju destinacije. Važno je pritom spomenuti da se proučavanje mračnog turizma nije zaustavilo samo na analizama i tematskim istraživanjima, već je potaknulo i osnivanje znanstvenog Instituta za istraživanje mračnog turizma na University of Central Lancashire (UK) 2005. godine, čime je ovaj specifični oblik turizma dobio svoju referentnu instituciju na globalnoj razini. (Kesar i Tomas, 2014., 52) Institut za mračni turizam (IDTR) ${ }^{1}$ zadužen je za izgradnju kapaciteta za istraživanja u području Mračnog turizma za povećanje kvalitete publikacija, upute o provedbi i upravljanju mračnih destinacija, kulturne baštine, znamenitosti i izložbi, uspostavljanje globalnog ugleda kao centar izvrsnosti za razvoj inovativnih $\mathrm{i}$ interdisciplinarnih pristupa u istraživanju turizma, povećanje razine lokalnih, nacionalnih i međunarodnih znanstvenih suradnji akademskih zajednica i medija te ažuriranje znanja o podučavanju i proučavanju Mračnog turizma. (University of Central Lancashire, England). Prema istraživanju motivacija Stone i Sharpley (2009., 21) razlikovali su u svome djelu nijanse mračnog turizma koje se vode prema intenzitetu doživljaja turista.

Kratica „IDTR“- engl. Institute for Dark Tourism Research 
Tablica 1: Nijanse mračnog turizma prema intenzitetu doživljaja turista

\begin{tabular}{|c|c|c|}
\hline & Područia smrti i patnie & $\frac{\text { Područja povezana sa }}{\text { smrti i patnjom }}$ \\
\hline Nijansa & Tamnija & Svjetlija \\
\hline Cilj & Edukacija & Zabava \\
\hline Svrha & Memorijalna & Kulturno nasljeđe \\
\hline Pristup & Komemoracija & Komercijalna \\
\hline Autentičnost & Stvarna & Priređena \\
Vrijeme od događaja & Kraće & Duže \\
\hline Turistička infrastruktura & Niža & Viša \\
\hline
\end{tabular}

Izvor: Stone i Sharpley, 2009., Mračnija strana putovanja, str. 21

Uz mračni turizam uvode se pojmovi poput tuge, žaljenja i patnje u cilju motivacije posjeta, dok su uobičajeni pojmovi koji se vežu uz turistički posjet, poput užitka, relaksacije i hedonizma, izgurani s liste prioriteta. Raine (2013., 248) je, po uzoru na Stona i Sharpley (2009., 21), proširio tablicu nijansi mračnog turizma. On identificira 9 kategorija koje počinju od najtamnije prema najsvjetlijoj po uzoru na istraživanje koje je proveo na tri područja pokapanja. U Rainovoj podjeli, mračniji turisti su oni koji planiraju putovanje na mračnu destinaciju, povezani su s lokacijom, doživljavaju na njoj duhovno iskustvo, zainteresirani su za specifičnosti lokacije i posjećuju je zbog specifičnog razloga. Svjetliji turisti najčešće dolaze slučajno, ne vežu se s lokacijom, duhovno su odvojeni te nemaju specifičan interes za mračnu lokaciju i moguće je da posjete više sličnih lokacija zbog istog razloga.

\subsection{Mračni turizam kao dio turističke ponude}

Turizam kao sociokulturni i gospodarski fenomen ima dvostruko djelovanje na prostor na kojem se razvija, trošeći ga i uništavajući s jedne strane, a s druge strane može znatno povećati njegovu vrijednosti i potražnju za njegovim atraktivnostima. U nastavku je pregled proizvoda koji se nude u sklopu mračnog turizma i koji nose značajne zasluge u razvitku destinacije u kojima se nalaze. Zbog rasprava o etičnosti mračnog turističkog proizvoda, u nastavku će biti izneseni neki od najčešćih proizvoda mračnog turizma koji su poredani prema emocionalnoj težini Stonea i Sharpley (2009.) počevši od „,najsvjetlijeg“ do „najmračnijeg“. 


\subsubsection{Mračna zabava}

Atrakcije Mračne zabave pojavljuju se na različitim područjima oživljavajući postojeće objekte ili stvarajući nove i usmjerena su ciljnim skupinama. Stvaranje ovakvih atrakcija može „rasteretiti“ turističku destinaciju masovnog turizma, preusmjeriti interes na manje razvijena područja, može sadržavati jednu ili više povezanih atrakcija te obogatiti postojeću turističku destinaciju. Kod ovog oblika bitan element je već postojeća destinacija/atrakcija ili priča koja će potaknuti interes i prodati proizvod. Najpoznatiji i najrašireniji primjer iz ovog koncepta predstavljaju „Tamnice“ ${ }^{\text { }}$ od Merlin Entertaiment grupe. Merlin Entertaiment je tvrtka sa 117 atrakcija u 24 zemlje na svijetu a Tamnice su koncept oživljavanja prošlosti kombinacijom legendi s povijesnim činjenicama u svrhu zabave i edukacije. Posjetitelji su u mogućnosti posjetiti tamnicu u trajanju od 90 minuta u koju su smještene mračne povijesne ličnosti i događaji iz Europe sa mnogo specijalnih efekata. U Londonskoj tamnici može se vidjeti priča o Jacku Trbosjeku ${ }^{3}$ i o periodu Crne Smrti (Kuge) u Europi. ${ }^{4}$ Primjer Mračne atrakcije su Drakula ture po Rumunjskoj (Light, 2017.). Naime, Drakula se spominje prvi puta u knjizi Bram Stokera pod imenom „Drakula“ čiju je radnju smjestio u Transilvaniju iako istu nikada nije osobno posjetio. Inspiraciju za svoju knjigu dobio je iz brojnih knjiga iz tog stoljeća gdje je pročitao o misterijama Transilvanijskih šuma te je trebao daleko mistično mjesto za smjestiti mračnog vampira Drakulu.

\subsubsection{Mračne edukacije}

Ova kategorija obuhvaća sve izložbe, muzeje i predstave koje rekreiraju i oživljavaju povijesna događanja u svrhu edukacije i poticanje sjećanja na tragične događaje. Za razliku od atrakcija Mračnih zabava, edukacijske atrakcije drže se činjenica i povijesnih događaja izbacujući legende i pretpostavke te isključuju zabavni sadržaj iz sadržaja atrakcija. Iako svrha postojanja ovakvih atrakcija je educiranje i komemoracija žrtava događaja te reflektirajuća poruka, svi oblici ovih atrakcija imaju neku razinu komercijalnog fokusa i turističke infrastrukture. Najčešće locirani podalje od mjesta događaja kojeg predstavljaju. Dobar primjer edukacijskog mračnog turizma je novoizgrađeni Smithsonian muzej američke povijesti koji prikazuje artefakte i slike napada 11. rujna. Izložba nosi naziv „11. rujna: svjedočenje povijesti“, namjerno je ograničena na samo 45 objekata za promatranje, jer svaki posjetitelj ,prilaže svoju emociju toj priči“. Izložba ima namjeru isprovocirati reakcije posjetitelja, ne ispričati priču o samom događaju, potičući emocije posjetitelja u svrhu „opraštanja“ sa proživljenim traumama uoči

Engl. The Dungeons

Engl. Jack The Ripper, neidentificirani serijski ubojica na području Londona 1888. godine

Više na : https://www.merlinentertainments.biz/the-dungeons (Pristup: 30.01.2018.) 
događaja. Ovakva provokacija i namjerno izazivanje u isto vrijeme pozitivnih i negativnih emocija kod posjetitelja, privukla je 7 milijuna ludi na izložbu „Body Worlds ${ }^{\text {“5 }}$. Body Worlds je izložba stvarnih trupala očuvanih posebnim tehnikama balzamiranja, zvanim ,plastination“, u kojima se koriste polimeri koji sprječavaju raspadanje tijela.

\subsubsection{Zatvori i tamnice}

Važnost postojanja zatvora i tamnica može se promatrati kroz više uglova i neosporivo su bitan resurs u turističkoj ponudi i ne samo kroz oblik Mračnog turizma. Mogu se promatrati kao kulturno nasljedstvo povijesne važnosti za jednu zajednicu, arhitektonski izričaj i kao uvid u društvo, politiku i socijalni poredak destinacije u prošlosti. (Stone, 2006, 2012.) Na primjer, „Galleries of Justice ${ }^{\text {"66 }} \mathrm{u}$ Nottinghamu u Engleskoj, koja ima nekonvencionalni način promoviranja kroz rečenicu ,jedino mjesto u državi gdje ste mogli biti uhićeni, optuženi i smaknuti“ popraćeno uz izjavu „najbolja obiteljska atrakcija u Engleskoj“. Osim što se mogu vidjeti prostorije sudnica, ćelija za pritvor optuženika i prostorija za smaknuće, muzej također nudi organiziranje rođendanskih zabava za djecu i vjenčanja u srednjovjekovnom okruženju. Sadržaj je prije svega edukativan te uvodi posjetitelje u povijest pravde engleske kroz tri stoljeća, a mračni dojam je ublažen interaktivnim sadržajem te turama posebno prilagođenima za različite uzraste posjetitelja. (Službena stranica Galleries of Justice).

S drugog spektra, manje „zabavan“ primjer od Galerija Pravde je Alcatraz Island izgrađen 1847. godine, smješten u San Francisco Bayu, mali otok koji od sadržaja ima svega jedan svjetionik, vojnu utvrdu i vojni zatvor koji je kasnije bio savezni zatvor od 1934. godine do 1963. godine. Danas je napušteni kompleks, zaštićen kao područje sa posebnim povijesnim značajem, otvoren za javnost i razgledavanjem turama koje kreću brodom iz San Francisca.

\subsubsection{Groblja}

Groblja imaju osim komemorativnog povijesni, kulturni i umjetnički značaj u destinaciji. Groblja ukazuju na povijest destinacije, razdoblja različitih vladavina po arhitektonskim izričajima po razdobljima u kojem su građeni nadgrobni spomenici. Otkako postoje kretanja ljudi groblja su posjećivana mjesta radi komemoracije pokojnika ili odavanja časti, međutim sve više raste iskorištavanje groblja, grobnica i počivališta u turističke i kulturne svrhe. Teško je odrediti mali

\footnotetext{
Engl. Svijet Tijela

Engl. Galerije Pravde
} 
broj motiva turista koji posjećuju neko groblje ili groblja, jer oni mogu biti vrlo različiti. Posjećivanje groblja radi komemoracije bliske osobe u veliko se razlikuje od posjećivanja groblja poznate ličnosti iz svijeta politike ili glazbe. Iz tog razloga, praćenje posjetitelja trebalo bi se izvršavati na starim grobljima, grobljima koja nisu otvorena za nove pokope, grobljima na kojima se plaća ulaz ili po broju rasprodanih karata za određene ture.

Na popisu UNESCO svjetske baštine nalazi se oko 50 groblja a u Europi postoji i organizacija The Association of Significant Cemeteries (ASCE), koja povezuje privatne i javne organizacije koje se brinu za značajna groblja Europe. Udruga pokriva 179 groblja u 22 europske zemlje. Iako značajna groblja, pokrivena groblja ASCE-om nužno ne privlače turiste zbog svoje značajnosti u arhitekturi ili povijesti jednako kao što privlače groblja sa neobičnim sadržajem ili pokopanih poznatih ličnosti.

Najbolji primjer „,neobičnog“ groblja nalazi se u Rumunjskoj, u pokrajini Maramureš $\breve{7}^{7}$ Groblje koje daleko odskače od pojma Mračnog nosi naziv na rumunjskom jeziku „Cimitilul Vesel" u prijevodu „Sretno groblje“. Naime, grobnice i spomenici su oslikani šarenim bojama i slikama pokojnika ili njegovog života, obično popraćeno sa humorističnom poezijom o životu pokojnika ili načinu na koji je umro. Lokalni umjetnik Stan I. Patraš, prvu oslikanu grobnicu napravio je 1935., a od tada se brojka povećala na čak 800 „sretnih“ grobnica. Danas, groblje je popraćeno sa raznim dodatnim sadržajima, ulaz se naplaćuje i oglašava se kao Rumunjska atrakcija koji se može organizirano posjetiti iz skoro svakog većeg grada u Rumunjskoj.

\subsubsection{Mračna svetišta}

Mjesta nesreća ili nesretnih događaja označavaju svako mjesto posjećeno zbog komemoracije osoba koje su tamo stradale neočekivanom smrću. Za potrebe ovog rada, ovakva područja označena su sa nazivom Mračna svetišta. Isključuje ratove i prirodne katastrofe. Formalne ili neformalne građevine su u blizini pogibije i nastaju nedugo nakon tragičnog događaja. Iako ove vrste atrakcija spadaju u tamniji spektar Mračnog turizma, one na važnosti danas dobivaju zbog popularizacije takvih područja od strane medija. Najčešće, nakon događaja stvori se prostor za ožalošćene za polaganje svojih simbola, cvijeća ili svijeća. Veliki broj ljudi putuje na mjesta tragedija, iako nisu direktno vezani za događaj, shodno sa velikim brojem ljudi, javlja se i određena organizacija na mjestu događaja tako da se nenamjerno stvara atrakcija od mjesta tragedije (Walter et. al. 1995., 583). Većina Mračnih Svetišta nisu turistički interesantna s obzirom na njihov

http://romaniatourism.com/maramures.html, pristup 05.12.2018. 
privremeni karakter i nedostatak infrastrukture, no oko tog vremena broj posjetitelja u ili oko prostora tragičnog događaja naglo poraste. Na primjer, svetište koje je izgrađen u sadašnjoj uobičajenoj cvjetnoj zgradi kod vrata Kensington Palače u vrijeme kada je Diana, princeza Walesa, ubijena 1997. godine, postala je središte za milijune ljudi. Ipak, u relativno kratkom razdoblju ovo je svetište demontirano i rekonstruirano u Althorp House. Althorp House je danas jedna od najpoznatijih atrakcija u Engleskoj, sadrži izložbe i kolekciju slika princeze Diane. Zanimljivo je da je više od desetljeća nakon njezine smrti posao sjećanja na Dianu ide dobro, a turistička infrastruktura u kući Althorp House razvija se tako da uključuje nagrađene izložbe koje ilustriraju Dianinu smrt (Merrin 1999., 53).

Nakon terorističkog napada na Svjetski trgovinski centar u New Yorku, 9.11.2001. godine milijuni ljudi su se skupljali kako bi vidjeli mjesto tragedije ili odali poštovanje žrtvama. Mnogi autori analizirajući kako je od mjesta tragedije nastala turistička atrakcija, došli do zaključka da je jedino mogla postati atrakcija zbog potrebe za voajerizmom i morbidnosti u ljudima. ${ }^{8}$ Mjesto tragedije danas je Memorijalni centar i muzej izgrađen točno na području nekadašnjeg Svjetskog trgovinskog centra poznatiji kao Ground Zero.

\subsubsection{Ratno područje}

Ratna područja veoma su osjetljiva i literatura je često kontroverzna zbog neslaganja između spomenika i komemoracije ali i prirode interpretacije ratnih atrakcija (Edwards 2000., 1), pri čemu su pojmovi "disonantna baština" (Tunbridge and Ashworth, 1996.) i političke ideologije često korijen tumačenja interesa. Kao primjer popularnih Ratnih Područja je Arnhem Bridge u Nizozemskoj, most koji je postao je poznat po strateškoj operaciji u Drugom svjetskom ratu poznatoj pod nazivom Operation Market Garden, pri čemu je most Arnhem bio posljednji u nizu strateških točaka koje su ciljale preuzeti savezničke snage. Popularizirana atrakcija kroz brojne knjige i film 1977. godine pod nazivom "A Bridge Too Far.” Tvornica emajla Oskara Schindlera u gradu Krakov u Poljskoj je još jedan primjer iz Drugog svjetskog rata, građevina o kojoj se moglo čitati u romanu Thomas Keneallya „Shindler's List" ili vidjeti u istoimenom filmu od redatelja Spielberga. Tvornica Oscara Shindlera koji je bio član nacističke stranke i koji je uspio spasiti stotine židovskih života podmićivanjem i zapošljavanjem Židova u tvornici emajla i streljiva. Danas ova administrativna zgrada sadržava Muzej suvremene umjetnosti i Povijesti muzej grada Krakova ${ }^{9}$.

8 Blair, J. (29.6.2002.) Tragedy turns to tourism at Ground Zero. The New York Times, (dostupno online: www.theage.com.au/articles/2002/06/28/1023864657451.html) (Pristup: 30.01.2018.)

9 http://oskarschindlerfactory.com (pristup: 30.01.2018.) 
Iako danas rijetki posjetitelji imaju vlastito sjećanje na Prvi i Drugi svjetski rat, događaji, bitke i priče oživljeni su kroz brojne filmove i potiču na posjet brojnih očuvanih destinacija koje su veoma turistički razvijene, sa brojnim popratnim sadržajem, izložbama, predstavama u kojima se „oživljavaju“ sukobi te efektima za dočaravanja mračnih vremena u povijesti. U ovaj oblik turizma obuhvaća se sve što je imalo direktnu poveznicu sa ratovima i bitkama, no isključuje koncentracijske kampove, genocide i masovne grobnice koje su rezultat rata.

\subsubsection{Područje genocida}

Glavni proizvod Područja Genocida je točna lokacija gdje se dogodilo masovno smaknuće, mučenje i zlodjela. Može se još zvati „Turizam Genocida“, „Holokaust turizam“ i sl. (Beech 2000, , 21). Ovaj oblik zauzima najmračniju sferu mračnog turizma. Smješteni su točno na mjestu događaja, sa građevinama sabirnih kampova, masovnim grobnicama, spomenicima ili drugim obilježjima područja. Najpoznatiji su Koncentracijski logori iz Drugog svjetskog rata koji se još nazivaju ,tvornice smrti“ u kojima je izgubilo život oko 3 milijuna ljudi. Postojalo je 66 kampova, najpoznatiji danas kao turistička atrakcija je Auschwitz. U Auschwitzu život je izgubilo oko 2 milijuna ljudi. Bliži primjer ove kategorije je genocid u Srebrenici koji se događao između 13. i 19. srpnja 1995. godine, tijekom rata u Bosni i Hercegovini. Izgrađen je Memorijalni centar u Potočarima, a otvorio ga je Bill Clinton. Rat u BiH dobiva Hollywood priču 2011.g. u filmu In the Land of Blood and Honey s glavnom ulogom glumice Angeline Jolie.

Kad se općenito raspravlja o mračnom turizmu, Područja Genocida djeluju kao krajnji, "najudaljeniji” rub spektra mračnog turizma. Stoga, Područja Genocida često šire mračni turistički koncept unutar javne i medijske psihe.

\subsection{Motivi turista za posjet mračnim destinacijama}

Prethodna istraživanja mračnih lokacija ukazuju na to da su motivacije za posjetom složene i različite, što rezultira mnoštvom razloga za doticaj sa sablasnim mjestima (Stone 2011.; Dale \& Robinson 2011.). Poznato je da je mračno turističko iskustvo subjektivno i da će se razlikovati od pojedinca do pojedinca, uključujući i njihov odnos prema mjestu (Robb, 2009., 332). U svjetlu tih različitih motivacija važno je napomenuti da se osnovni poriv za posjet mračnim lokacijama nalazi u "pseudo-vezi” (Stone 2011., 93) kako bi se prihvatila neka osoba ili događaji.

Seaton i Lennon (2004., 63) dodaju da mračni elementi u destinaciji nisu glavna motivacija za putovanje niti su prioritetna aktivnost na putovanju, već dio 
cijelog putovanja, a da zadovoljavaju potrebu putnika da vidi nešto što ostali nisu i da zadovolji svoju znatiželju. Timothy (2011., 7) tvrdi da svaki čovjek ima u sebi znatiželju o smrti. Prema ovome, mračne atrakcije su „gurajući faktor“ jer je glavni motiv znatiželja, a ona nije, kao što se može vidjeti u prošlom djelu rada, izazvana sadržajem i turističkom infrastrukturom na mračnim područjima. Crompton (1979., 419) tvrdi kako je znatiželja povezana sa jedinstvenim iskustvom ponuđenim od mračne destinacije. Naime, jedinstvenost mračno je faktor „privlačenja“. Paralelno s time, uloga medija u privlačenju ne smije se zanemariti (Seaton i Lennon 2004., 65) izvještavanje o tragedijama, moć interneta i brzog širenja vijesti budi znatiželju te lokacije preko noći postaju turističko odredište u kojem je potpuno odsutna turistička infrastruktura. Mayo i Jarvis (1981., 17) tvrde da je svaki čovjek rođen sa određenom dozom da istraži svijet, i bude prvi u otkrivanju „blaga“.

\subsection{Promocija mračnih destinacija}

Postoji više načina transformacije mračne lokacije u turističku atrakciju putem autonomnih imidž agenata. Prilično drastični iznenadni primjeri su bombaški napad na WTC 11. rujna 2001. godine, uragan u New Orleansu 2006. godine, smrt princeze Diane i Doda Fayeda u tunelu autoceste u Parizu, serijska ubojstva u Sohamu i Gloucesteru u Engleskoj i slično. Ova događaja su stvorila identitet tih mjesta bez ikakvih marketinških akcija od strane destinacija, a ipak su počela privlačiti znatiželjne posjetitelje. Rezultat je bio da su lokacije tragedije iznenadno morale nositi sa problemom turističkog menadžmenta, ograničenjima turističke aktivnosti, kontroliranjem broja posjetitelja i slično. Mediji koji rapidno prenose informacije, stvaraju mračne turističke destinacije iznenada, prisiljavajući menadžere javnih sektora da postaju turistički planeri htjeli to oni ili ne." (Sharpley, 2014., 90)

Pitanje etičnosti razvitka i promoviranja mračne destinacije je jedno od najosjetljivijih točaka. Postavlja se pitanje želi li se „komercijalizirati“ dio tragične povijesti, što opet vodi ka nužnosti određivanja stupnja emocionalne „težine“. Za ovaj problem, direktno se veže i problem promocije i marketinga mračne destinacije. Naime, mračna destinacija se rijetko kada gradi (izuzev tematskih parkova, zabavnih kuća strave i sl.), ona se dogodi i jednako tako iznenada pojavi se i neplanirana (ili neželjena) promocija (mediji, vijesti, priče, legende i sl.). Kada se dogodi neplanirana promocija destinacije, problem je odrediti tko će preuzeti odgovornost za daljnje poticanje ili sprečavanje turističke aktivnosti. Nakon što je priča o događaju dostupna javnosti, javlja se problem interpretacije. 


\subsection{Potencijal mračnog turizma u Hrvatskoj}

Prema britanskom Telegraphu (2014.), ali i brojnim drugim relevantnim izvorima, među globalno najpopularnijim memorijalnim lokalitetima najčešće se spominju: Auschwitz (Krakow, Poljska), Alcatraz (San Francisco, SAD) i Ground Zero (New York, SAD), Chernobyl (Pripyat, Ukrajina), Muzej genocida Toul Sleng (Choeung Ek, Kambodža), Hiroshima (Japan), bojna polja Hastings, Bosworth i Culloden (UK), Gettysburg (SAD) i Waterloo (Belgija) i dr (Kesar i Tomas, 2014.).

Povijest Hrvatske duboko je prožeta brojnim političkim i društvenim previranjima koja su nerijetko prerasla u ratne sukobe i progonstva. Zbog brojnih vojnih i civilnih žrtava koje su svoje živote položili za slobodu (u bilo kojem smislu), u Hrvatskoj se danas nalaze brojni memorijalni lokaliteti na kojima se iskazuje individualna i kolektivna empatija te oplakuju stradali (Kesar i Tomas, 2014.) Jasenovac, Goli Otok i Vukovar imaju velik potencijal za daljnji razvoj mračnog turizma u Hrvatskoj prema kategorijama velike povijesne važnosti, međutim kao svjetliji mračni turizam u Hrvatskoj može se spomenuti općina Tinjan koja bi pripadala kategoriji Mračne zabave.

\section{METODOLOGIJA ISTRAŽIVANJA}

Istraživanje je provedeno na uzorku od 189 ispitanika u periodu 10.svibnja do 20 . svibnja 2017.g. Instrument istraživanja bio je anketni upitnik, izrađen pomoću Google obrasca i sastojao se iz nekoliko dijelova. Svrha ovog istraživanja bila je saznati razumiju li ispitanici uopće pojam mračnog turizma te analizirati njihove stavove o istome. Mnogi od onih koji su pisali o mračnom turizmu tražili su kvalitativne istraživačke metode (Novelli 2005.) i usredotočili se na filozofska pitanja i motive, koji su evoluirali istraživanje tamnog turizma pa se sada može prikladno testirati kvantitativno.

Etički, anketa nije prikupila nikakve osobne podatke niti snimila imena ili druge povjerljive informacije; dopuštajući anonimnost, pretpostavilo se da će sudionici odgovoriti iskreno. Iako se predmetna tema može smatrati "osjetljivom", pa čak i "uvredljivom", pitanja su uglavnom bila općenita i nisu pokušavala emocionalno angažirati sudionika. Ograničenja kvantitativnih istraživanja uključuju zatvorena pitanja, koja ne dopuštaju dubinu odgovora, kao i otkrivanje neočekivanih rezultata koji se više ne mogu istražiti.

Istraživanjem se prikupilo 189 odgovora u čijoj strukturi neznatno prevladavaju muški ispitanici s udjelom od 54\%. Većina odgovora $(93,1 \%)$ bila su od ispitanika u dobi od 19-35 godina pa se može reći da uzorak predstavlja mlađu populaciju, 
što se i očekivalo obzirom na online dostupnost ankete. Takva je ciljna publika poželjna za potrebe ovog ispitivanja jer je pretpostavka da pojam mračni turizam povećava interes među putnicima mlađe životne dobi, koji stvaraju trendove i kreiraju budućnost putovanja. Mlade generacije putnika obilježava individualizam, potraga za različitim iskustvima (jedinstvenim proizvodom), aktivnosti na odmoru u svrhu samoostvarenja i povećanja društvene i ekološke svijesti. Anketa je pisana na hrvatskom jeziku kako bi se selektirao uzorak na turiste iz Hrvatske i okolnih zemalja (Srbije, Bosne i Hercegovine, Slovenije, Kosova, Makedonije i Crne Gore) Većina ispitanika bila je hrvatskog državljanstva (147).To nažalost ne dopušta značajnu usporedbu između pripadnika različitih državljanstava i dobi ispitanika, ali ipak daje sliku dojma mladih putnika prema mračnom turizmu.

\section{REZULTATI ISTRAŽIVANJA}

Istraživanje je pokazalo da većina ispitanika (84,1\%) putuje u svom vlastitom aranžmanu dok samo $15,3 \%$ putuje preko turističkih agencija. Rezultat je očekivan prema pretežito mlađoj dobi ispitanika. Također, na slijedeće pitanje na koji način ispitanici rezerviraju svoj smještaj, većina je odgovorila preko specijaliziranih stranica na internetu (npr. Airbnb i Booking.com) kao i samostalnim pretraživanjem interneta. Ova saznanja potvrđuju činjenicu da je riječ o mlađoj populaciji spremnoj na samostalno istraživanje lokacija i smještaja u njihovim interesima, što ih je činilo prigodnim uzorkom za potrebe ispitivanja. Iz tog razloga postavljeno je pitanje koje je vjerojatno izazvalo nejasnoće kod ispitanika, no upravo to i je cilj.

Prvo pitanje glasilo je „Jeste li čuli za mračni turizam prije?“. $82 \%$ ispitanika nije nikada čulo za termin „mračni turizam“ dok je $18 \%$ ispitanika tvrdi da su čuli za mračni turizam prije ispitivanja. Bilo je očekivano da će vrlo mali broj ispitanika biti upućeno u termin mračnog turizma. Vjerojatno bi poznavatelji engleskog jezika znali i prepoznati pojam ,dark tourism“ zbog nepovezanosti pojmova ,dark“ s ilegalnim radnjama kao što je to u hrvatskom jeziku „turizam na crno“ ili „rad na crno."

Drugo pitanje je bilo „Što mislite što predstavlja "Mračni turizam”?“ Pitanje je bilo namijenjeno provjeri znanja prije početka ispitivanja o specifičnim destinacijama. 
Tablica 2: Pretpostavke ispitanika o značenju termina “mračni turizam” (N=189)

\begin{tabular}{|c|c|}
\hline Termin & Broj \\
\hline Posjećivanje područja patnje & 68 \\
\hline Turizam razorenih područja & 65 \\
\hline Ilegalni turizam & 56 \\
\hline Posjećivanje mračnih područja i građevina & 44 \\
\hline Ratni turizam & 40 \\
\hline Turizam u mjestima siromaštva & 29 \\
\hline Turizam narkotika & 28 \\
\hline Sex turizam & 23 \\
\hline
\end{tabular}

Izvor: rezultati istraživanja

Slika 1: Pretpostavke ispitanika o značenju termina "mračni turizam" $(\mathrm{N}=189)$

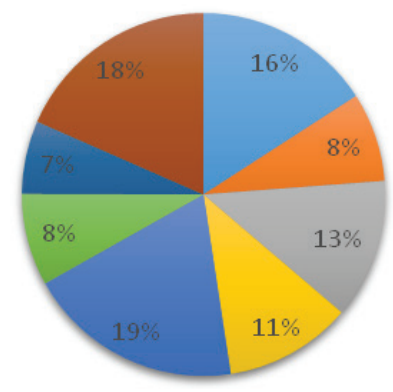
- Ilegalni turizam
- Turizam narkotika
- Posjećivanje mračnih područjai građevina
- Posjećivanje područja patnje
- Turizam u mjestima siromaštva
- Sexturizam
- Turizam razorenih područja

Izvor: rezultati istraživanja

Kao i u prethodnom pitanju, pretpostavka autora se potvrdila. Pretpostavka je bila da će ,mračni turizam“ biti asociran ilegalnim turizmom. Pretpostavlja se da je to zbog slične terminologije budući da se za ilegalni turizam koristi naziv ,turizam na crno“. Slijedeće pitanje „Koje emocije Vam se pojave kada čujete pojam 'mračni turizam'?“ važno je pitanje za samu percepciju pojma zbog toga što još nisu podijeljene nikakve informacije iz kojih bi ispitanik mogao vidjeti što taj pojam zapravo znači. Svrha pitanja bila je dobiti uvid u prve asocijacije sa pojmom „mračni“" turizam te u kojoj mjeri je asocijacija negativna. 
Tablica 3: Emocija ispitanika na pojam "mračni turizam"

\begin{tabular}{|c|c|}
\hline Emocija & Broj \\
\hline Znatiželju & 97 \\
\hline Strah & 64 \\
\hline Interes & 61 \\
\hline Želju za znanjem & 50 \\
\hline Morbidnost & 49 \\
\hline Tugu & 31 \\
\hline Fascinacija & 21 \\
\hline Želja za avanturom & 20 \\
\hline Gađenje & 17 \\
\hline Uzbuđenost & 15 \\
\hline Ostalo & 6 \\
\hline
\end{tabular}

Izvor: rezultati istraživanja

Najviše ispitanika odabralo je ,znatiželju“ a nakon toga ,strah“ i ,interes“. Među odgovorima pod „ostalo“ može se pronaći ,odbojnost“", „destrukcija“. Prema odgovorima primjećuje se konflikt između znatiželje i ostalih „negativnih“ emocija što je izravno vezano za nepoznavanje sadržaja.

Nakon pitanja gdje su ispitanici vrlo vjerojatno nagađali značenje mračnog turizma, slijedilo je pitanje koje razjašnjava pojam mračnog turizma, tj. zanemarile emocije izazvane te se jasno odabrala kategorija u koju naziv „mračni turizam“ pripada ispitaniku. Pitanje glasi „Da li Vam se sviđa naziv “mračni turizam?” 78 ispitanika (41,3\%) je označilo ,Da, zvuči interesantno!“" 71 ispitanik $(31,6 \%)$ označilo je „Ne, zvuči negativno!“‘ a 40 ispitanika $(21,2 \%)$ označilo je „Ne znači mi ništa".

Slično kao izjava Sharpleya (2014.) da sukobljena kombinacija riječi "mračna" ili "tuga" s "turizmom" stvara "privlačnost pozornosti" i "zavodljiv naslov". Doista, "pokriveno kategoriziranje posjeta mjestima ili događajima ili povezano sa smrću kao "mračnim turizmom" pojednostavljuje i skriva mnoštvo značenja i ciljeva” (Sharpley, 2014., 250). Na pitanje da li „,voli“ izraz tamni turizam, Sharpley se izrazio: "Ne, nepoželjan pojam - u početku atraktivan, ali u konačnici preširok, primjenjuje se na same turiste i vrlo malo oblika turizma može biti kategoriziran mračnim iz perspektive ponašanja”. Čini se da Sharpley nije sam u svom razmišljanju i vjerojatno zbog valjanog razloga, jer se pojmom „mračni turizam" obilježava širok spektar odredišta i atrakcija. Iz akademskog stajališta pojam je preširok, iako omogućuje kontinuirano i više usmjereno istraživanje, no s marketinškog gledišta, povećava interes i svijest. Sharpley tvrdi da "Iz komercijalne i potencijalno eksploatativne perspektive to je sjajan način privlačenja pozornosti od strane trgovaca, ali nije u konačnici tama koja privlači ljude, barem ne one bez voajerskih tendencija". 


\section{ZAKLJUČNA RAZMATRANJA I OGRANIČENJA ISTRAŽIVANJA}

Cilj istraživanja bilo je prikupljanje mišljenja i dojmova o promicanju mračnog turizma jer postoje brojna sukobljena razmišljanja unutar akademske zajednice. Ovim radom pokušalo se pojednostaviti složen pojam i pružiti sliku percepcije mladih ispitanika o mračnom turizmu. Istraživanje je proizvelo opća saznanja o mračnom turizmu, a istraživanje bilo dublje kada bi bilo više usmjereno na promociju i kreiranje određenih mračnih proizvoda. Rezultati su otkrili da postoji možda veći interes, nego što se moglo očekivati od mlade demografske skupine. Općenito, mračni turizam je prepoznat kao specifičan oblik, edukativnog i zanimljivog sadržaja, različite emocionalne težine.

U ovom istraživanju pokazalo se da mračni turizam nije društveno neprihvaćena pojava, već da mračni lokaliteti, uzimajući u obzir vrstu proizvoda, pružaju povijesnu, komemoracijsku, kulturnu i umjetničku vrijednost. Otvoren je prostor za buduća istraživanja u području razlučivanja između kulturno povijesne baštine i mračnog turizma i određivanja granice primjerenosti kreiranja turističke ponude na određenim lokacijama. Također nije poznato hoće li razdvajanje mračnog turizma u kategorije utjecati da pojedine lokacije postanu krajnje mračne i društveno neprihvatljive dimenzije.

Proizvode mračnog turizma treba promatrati kroz usmjerenija istraživanja zbog njihove prirode pojačane društvene osjetljivosti i razvijati ih u skladu sa emocionalnom težinom koju izazivaju kada se plasiraju na tržište. Potražnja za mračnim proizvodima je heterogena, motivi su izrazito različiti te ovise o nijansama mračnog lokaliteta te razinom direktne ili indirektne povezanosti s tematikom mračnog proizvoda.

Ovaj rad može poslužiti kao uvod u nedovoljno istraženo područje u Hrvatskoj te poslužiti kao polazna točka za daljnja istraživanja koja bi s vremenom mogla doći do identifikacije potencijala Hrvatske u eksploataciji novog segmenta turizma koji je na neki način ostao zanemaren u kreiranju identiteta Hrvatske kao destinacije. Nedvojbeno je da Hrvatska sadrži mnogo kulturnih znamenitosti, stvarnih događaja, priča i legendi, koji ostaju u usmenim predajama i starim zapisima, a turistički su neiskorišteni, iako u sebi sadrže veliki potencijal koji čeka na primjereno integriranje u mračni proizvod Hrvatske. Podrazumijeva se, da se prije upotrebe mračnog turizma kao sredstva promocije turističke destinacije, otkrije kako kreirati i plasirati ,primjerni“ mračni proizvod na tržište, a to pitanje je ujedno i polazište za daljnja istraživanja i nove primjenjive spoznaje. 


\section{LITERATURA}

1. Beech, J. (2000.) The Enigma of Holocaust Sites as Tourist Attractions - The Case of Buchenwald. Managing Leisure, no.5, pp. 29-41.

2. Crompton, J. L. (1979.). Motivations for pleasure vacation. Annals of Tourism Research, vol. 6 no.4, pp. 408-424.

3. Dale, C. \& Robinson, N. (2011.) Dark Tourism. In Robinson, P., Research themes for tourism and leisure, pp. 205-215. Oxford: CABI.

4. Edwards, P. (2000.) Mort pour la France: Conflict and Commemoration in France after the First World War. Journal of Contemporary History Vol 1, pp. 1-11

5. Geić, S. (2011.) Menadžment selektivnih oblika turizma, Split: Sveučilište u Splitu, Sveučilišni studijski centar za stručne studij

6. Kesar, O., Tomas, P. (2014.): “Obilježja i dosezi razvoja memorijalnog turizma u Hrvatskoj”, Liburna, vol.3, no. 1, Zadar, str. 49-88; ISSN: 1848-5332

7. Light, D. (2017.) 'The undead and dark tourism: Dracula tourism in Romania', in G. Hooper and J.J. Lennon (eds) Dark Tourism: Practice and Interpretation, Routledge, Abingdon, 121-133

8. Luković, T. (2008.): Selektivni turizam, hir, ili znanstveno istraživačka potreba, Acta turistica nova, Vol 2, no 1, pp 51-74

9. Mayo, E. \& Jarvis, L. (1981.) The psychology of leisure travel: effective marketing and selling of travel services. Boston: CBI Publishing.

10. Merrin, W. (1999.) Crash, Bang, Wallop! What a Picture! The Death of Dia$n a$ and the Media, Mortality, vol.4 no.1, pp. 41- 62

11. Novelli, M. (2005.) Niche Tourism: Contemporary issues, trends and cases. Oxford: Butterworth-Heinemann.

12. Raine, R. (2013.) A dark tourist spectrum. In International Journal of Culture, Tourism and Hospitality Research: vol. 7 no. 3, pp. 242 -256.

13. Richards, G. (1996.) Cultural Tourism in Europe. CAB International, Wallingford.

14. Robb, E.M. (2009.) Violence and recreation: vacationing in the realm of dark tourism. Anthropology and Humanism, vol. 34 no. 1, pp. 51-60.

15. Ryan, C., and Kohli, R., (2006.) The Buried village, New Zealand - An example of dark tourism? Asia Pacific Journal of Tourism Research Vol. 11, Iss. 3.

16. Seaton, A. V., and Lennon, J. (2004.) Moral panics, ulterior motives and alterior desires: thanatourism in the early 21st century. In T. V. Singh, (Ed.), New horizons in tourism: strange experiences and stranger practices. ( pp. 63-82). Wallingford: CABI. 
17. Sharpley, R. (2014.). Towards an understanding of 'genocide tourism'. Contemporary Tourist Experiences: Concepts and Consequences, Abington, Oxon: Routledge

18. Stone, P. \& Sharpley, R. (2008.) Consuming dark tourism: a thanatological perspective. Annals of Tourism Research, vol. 35 no. 2 , pp. 574-595

19. Stone, P., \& Sharpley, R. (2009.). The darker side of travel: The theory and practice of dark tourism. Bristol: Channel View.

20. Stone, P. (2006.) A dark tourism spectrum: towards a typology of death and macabre related tourist sites, attractions and exhibitions. Tourism: An International Interdisciplinary Journal, vol. 54, no.2, pp. 445-160.

21. Stone, P. (2011.). Dark tourism: towards a new post-disciplinary research agenda. International Journal of Tourism Anthropology, vol. 1, no. 3, pp. 318-332

22. Stone, P. (2012.) Dark tourism and significant other death: Towards a model of mortality mediation, Annals of Tourism Research, vol.39, no. 3, pp. 1565-1587

23. Timothy, D.J. (2011.) Cultural heritage and tourism: An introduction. Channel View Publications

24. Tunbridge, J. and Ashworth, G. (1996.) Dissonant heritage: The management of the past as a resource in conflict. Chichester; Wiley.

25. Walter, T., Littlewood J., Pickering, M. (1995.) Death in the news: the public invigilation of private emotion, PickeringSociology, vol. 29, no. 4 , pp. 579-596

\section{Internet izvori:}

1. Državni zavod za statistiku, Turizam - kumulativni podaci po godinama, Zagreb : http://www.dzs.hr (Preuzeto: 18.09.2017.g.)

2. Programa ukupnog razvoj općine Tinjan 2015.-2020.: http://www.tinjan.hr/ Home/DocumentDetail/ec2fa261-b41e-4af6-bd7c-b3796ddaa7cb (Preuzeto $05.02 .2018 . \mathrm{g})$

3. Službena stranica ASCE organizacije: http://www.significantcemeteries. org/2018/03/wdec-and-agm-events-labeled-as-european.html (Preuzeto 05.02.2018.g)

4. Službena stranica Galleries of Justice: http://www.galleriesofjustice.org.uk) (Preuzeto 05.06.2018.g)

5. Službena stranica općine Tinjan: http://tinjan.hr/Home/Index (Preuzeto 12.3. 2018.g) 
6. Spomen područje Jasenovac http://www.jusp-jasenovac.hr (Preuzeto: 15.03.2018.g.)

7. Turistička zajednica grada Vukovara: http://www.turizamvukovar.hr/index. php?stranica=247\# (Preuzeto: 15.03.2018.g.)

8. Svjetska turistička organizacija: http://www.unwto.org/ (Preuzeto 15.03.2018.)

9. Službena stranica rumunjskog turističkog ureda: http://romaniatourism. com/maramures.html, (Preuzeto: 05.12.2018.) 


\title{
Ana Njegovan, mag.oec.
}

Faculty of Tourism \& Hospitality Management, University of Rijeka, Rijeka, Croatia ananjegovan@gmail.com

\section{Lidija Bagarić, PhD}

Faculty of Tourism \& Hospitality Management, University of Rijeka, Rijeka, Croatia lidijab@fthm.hr

\section{THE POTENTIAL OF DARK TOURISM AS A DESTINATION TOURIST PRODUCT}

Received: January 23, 2019

Accepted: August 26, 2019

https://doi.org/10.46458/27121097.2020.26.9

\section{Preliminary communication}

\begin{abstract}
Travel to places associated with death, disaster and destruction become a growing dimension of contemporary tourist supply in tourist packages because they provide potentially more meaningful travel from the passenger's point of view. There is an increasing number of tourists looking for differentiated, individually tailored and spiritually valuable tourist products, among which are products that threat life and death or "revive" controversial parts of the past. As a result of the demand for such products, quite emotional label links to this type of tourism, called "dark tourism", which preoccupies the public and the academic community in the continuous growth of the need for further research. However, despite intensified interest, the literature is scarce, and the theories are filled with unanswered questions and doubts.

In this paper, at least conceptually, the aim is to determine the fundamental features of dark products and the characteristic and perception of the dark supply through the "shades" theory of places and the emotionality that the potential location contains. Furthermore, this research has resulted in the knowledge that dark tourism products, with different characteristics and shades, can play an important role in improving the tourist destination product.
\end{abstract}


The paper analyses the views on the concept of dark tourism and has approached the answer to the question of whether dark tourism is an acceptable tourist product and its importance for a tourist destination.

Keywords: selective tourism, dark tourism, shades of darkness, destination product;

JEL: M31, O21, L83, R11 